\author{
Agnieszka DZIERŻAWA ${ }^{1}$, Jolanta WYRÓD-WRÓBEL ${ }^{2}$ \\ Opiekun naukowy: Jolanta WYRÓD-WRÓBEL ${ }^{2}$
}

DOI: https://doi.org/10.53052/9788366249844.06

\title{
IMPREZY MASOWE ORGANIZOWANE PRZEZ UCZELNIE WYŻSZE
}

\begin{abstract}
Streszczenie: Przed organizatorami imprez masowych stoi wiele wyzwań. Sprostanie tym wyzwaniom wymaga zaangażowania ze strony wielu osób, firm, organizacji itd.

W artykule przedstawiono wyniki badań ankietowych przeprowadzonych wśród studentów/uczestników imprez masowych. Na podstawie przeprowadzonej analizy można powiedzieć, że badana grupa respondentów jest zadowolona z udziału w imprezach masowych organizowanych przez uczelnie wyższe, ankietowani najczęściej biorą udział w takich wydarzeniach, jak: Juwenalia oraz Targi pracy. Wśród kryteriów, które powinny zostać poprawione wskazane zostały: ochrona imprezy, zaplecze higieniczno-sanitarne oraz zabezpieczenie medyczne.
\end{abstract}

Słowa kluczowe: satysfakcja klienta, imprezy masowe, organizacja

\section{MASS EVENTS AT UNIVERSITIES}

Summary: There are many challenges which event organizers need to face. Meeting these challenges requires the involvement of many people, companies, organizations, etc.

The article presents the results of surveys conducted among students / participants of mass events. Based on the analysis, it can be said that the surveyed group of respondents is satisfied with a participation in mass events organized by universities. Most often respondents take part in events such as Juwenalia and Job Fairs. The criteria that should be improved include: protection of the event, hygienic and sanitary facilities and also the medical protection.

Keywords: customer satisfaction, mass events, organization

\section{Imprezy masowe}

Imprezy masowe są na stałe wpisane w historię dziejów ludzkości. Od wieków stanowiły rozrywkę skierowaną do szerokiego grona odbiorców. Wraz z rozwojem gospodarczym, postępem technologicznym wypracowywane są co raz to nowsze rozwiązania, które nie tylko usprawniają i ułatwiają pracę organizatorom takich

\footnotetext{
${ }^{1}$ Akademia Techniczno-Humanistyczna w Bielsku-Białej, Wydział Zarządzania i Transportu, specjalność: Zarządzanie Logistyką i Jakością, agnieszka.dzierzawa@gmail.com

${ }_{2}$ dr inż. Akademia Techniczno-Humanistyczna w Bielsku-Białej, Wydział Zarządzania i Transportu,jwyrod@ath.bielsko.pl
} 
wydarzeń ale również przyczyniają się do satysfakcji uczestników biorących w nich udział.

Imprezy masowe generują ogromne koszty ale są również źródłem dochodów dla organizatorów (przedsiębiorstw, organizacji, samorządów terytorialnych) oraz innych podmiotów, w tym: hoteli, punktów gastronomicznych, komunikacji miejskiej itd.[9]. Jest to również doskonała okazja do stosowania różnych narzędzi i form promocji. Dzięki nim możliwe jest kreowanie pozytywnego wizerunku regionu, marki, popytu czy potrzeb konsumenckich. Jednakże, wybór określonych narzędzi i form promocji zależy od różnych czynników. W odniesieniu do czynników promocyjnych miasta mogą to być np.[7]: wielkość, pozycja i funkcje miasta, strategia rozwoju miasta, środki finansowe jakimi dysponuje miasto, gmina, region, działalność promocyjna, w tym zasięg przestrzenny działań promocyjnych (lokalny, ponadlokalny, regionalny, krajowy czy międzynarodowy) [3].

Imprezy masowe mogą mieć różny charakter. Mogą to być imprezy sportowe, muzyczne, pokazy, pikniki, wystawy itd.

Wyróżnić można następujące typy imprez masowych [2]:

- $\quad$ megaevents, np. igrzyska olimpijskie czy mistrzostwa świata,

- $\quad$ charakterystyczne imprezy, są najczęściej wizytówką danego miasta czy regionu i są z nim nierozłącznie utożsamiane np. Tour de Pologne, Tour de France, Octoberfest itp.,

- ważne/znaczące imprezy, przyciągają dużą liczbę uczestników, zawodnicy biorący udział w tego typu wydarzeniu reprezentują różne kraje, np. zawody na Wielkiej Krokwi w Zakopanem,

- $\quad$ imprezy lokalne, obejmujące społeczność danego regionu (gmina bądź miasto). Natomiast Ustawa z dnia 20 marca 2009 r. o bezpieczeństwie imprez masowych podaje następujący podział tego typu wydarzeń [10]: impreza artystycznorozrywkowa oraz impreza sportowa, w tym mecze piłki nożnej.

W tej klasyfikacji nie mieszczą się natomiast imprezy [10]:

- organizowane w obiektach kulturalnych, takich jak: teatry, filharmonie, kina, muzea, itp.,

- $\quad$ przez osoby zarządzające placówkami oświatowymi,

- $\quad$ w ramach współzawodnictwa sportowego dzieci i młodzieży,

- imprezy sportowe dla osób niepełnosprawnych,

- organizowane na otwartym terenie, o charakterze nieodpłatnym i ogólnodostępnym,

- $\quad$ organizowane przez pracodawców dla pracowników, o ile impreza odpowiada przeznaczeniu obiektu lub terenu, na którym jest organizowana.

Imprezy masowe są wielkim wyzwaniem organizacyjnym i logistycznym z uwagi na liczbę osób biorących w nich udział. W przypadku obiektów zamkniętych liczba uczestników musi przekraczać 500 osób, a dla obiektów otwartych typu stadion 1000 [10].

Za bezpieczeństwo imprezy masowej w miejscu i czasie jej trwania odpowiada jej organizator, którym może być osoba prawna, osoba fizyczna lub jednostka organizacyjna nieposiadająca osobowości prawnej. Wszelkie działania związane z impreza masową są podejmowane: przed imprezą, w czasie jej trwania, a także po jej zakończeniu. Ich celem jest nie tylko zapewnienie rozrywki uczestnikom, ale również zapewnienie bezpieczeństwa i porządku publicznego. Wymaga to wdrożenia 
i zastosowania wielu procedur mających na celu zwiększenie bezpieczeństwa i zapewnienie ochrony (zdrowia, życia, mienia) jej uczestników. Taki obowiązek spoczywa nie tylko na organizatorze, ale także na innych podmiotach, np. takich jak: wójt, burmistrz, prezydent miasta, wojewoda, Policja czy Państwowa Straż Pożarna wraz z zespołami i służbami wykonującymi zadania na rzecz bezpieczeństwa i porządku publicznego [8].

Bezpieczeństwo imprezy masowej obejmuje spełnienie przez organizatora wymogów w zakresie [5]:

1. Zapewnienia bezpieczeństwa osobom uczestniczącym w imprezie, ochrony porządku publicznego, zabezpieczenia medycznego, technicznego obiektów budowlanych wraz ze służącymi tym obiektom instalacjami i urządzeniami technicznymi, w szczególności przeciwpożarowymi i sanitarnymi,

2. Spełnienia wymogów określonych $\mathrm{w}$ przepisach prawa budowlanego, w przepisach sanitarnych i przepisach dotyczących ochrony przeciwpożarowej,

3. Udziału służb porządkowych, służb informacyjnych oraz kierującego tymi służbami kierownika do spraw bezpieczeństwa, pomoc medyczną, zaplecze higieniczno-sanitarne,

4. Wyznaczenia dróg ewakuacyjnych oraz dróg umożliwiających dojazd pojazdom służb ratowniczych i Policji,

5. Zorganizowania łączności pomiędzy podmiotami biorącymi udział w zabezpieczeniu imprezy masowej,

6. Sprzętu ratowniczego i gaśniczego oraz środków gaśniczych niezbędnych do zabezpieczenia imprezy masowej,

7. Wydzielenia pomieszczeń dla służb kierujących zabezpieczeniem imprezy masowej.

Organizatorzy imprezy masowej muszą mieć na względzie bezpieczeństwo uczestników, a tym samym brać pod uwagę możliwość wystąpienia zagrożeń o różnym charakterze, w tym pożaru, katastrofy budowlanej, zamachu terrorystycznego, aktów chuligaństwa itd. Zagrożenia te w wielu przypadkach są spowodowane przez czynnik ludzki i mogą wpłynąć na pojawienie się sytuacji kryzysowej [6]. Wśród tych zagrożeń są takie, które można przewidzieć oraz te, których nie tylko nie da się przewidzieć, ale nawet w pełni zidentyfikować ich źródeł. W organizację uczelnianej imprezy masowej zaangażowany jest zespół osób, w którego skład wchodzą m.in. pracownicy uczelni, studenci, przedstawiciele miasta. Przebieg wydarzenia, miejsce oraz budżet muszą być szczegółowo zaplanowane.

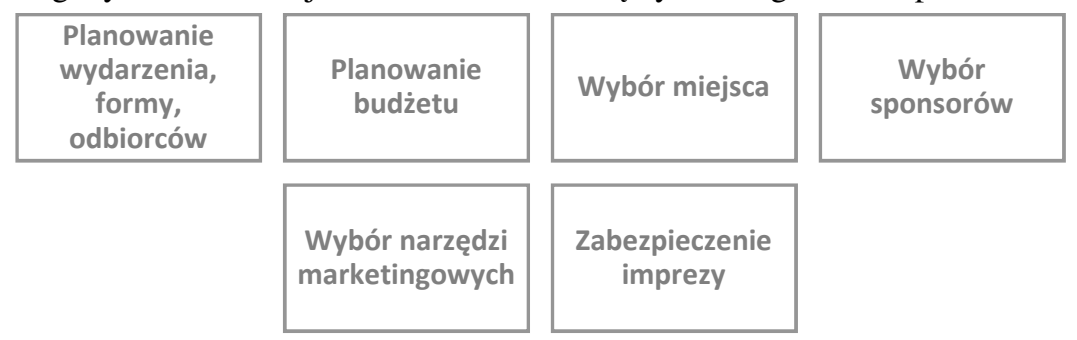

Rysunek1. Kryteria istotne przy planowaniu imprezy masowej

Źródto: Opracowanie własne 
Rysunek 1 przedstawia schemat kryteriów branych pod uwagę przy planowaniu imprezy masowej. Planowanie wydarzenia jakim jest impreza masowa wymaga oprócz zdefiniowania odbiorców, doboru zespołu, opracowania wstępnej koncepcji (planu) tego wydarzenia. Należy określić formę wydarzenia np. czy będzie to koncert, zawody itp. oraz zaplanować atrakcje, które będą przewidziane dla uczestników w trakcie trwania imprezy. Ważną kwestią jest rezerwacja terminu, w którym impreza ma się odbyć oraz jej zgłoszenie do odpowiednich jednostek np. komendanta (powiatowego, rejonowego, miejskiego) Policji, komendanta (powiatowego, miejskiego) Państwowej Straży Pożarnej. Zgłoszenie powinno nastąpić nie później niż 30 dni przed rozpoczęciem imprezy.

Drugim ważnym aspektem jest stworzenie kosztorysu, w którym zawarte będą wszystkie punkty przedsięwzięcia, a następnie pozyskanie funduszy na ich realizację. Organizatorzy imprez masowych mają do dyspozycji 2 źródła finansowania imprezy, są nimi środki własne oraz środki obce np. pochodzące od sponsorów (rysunek 2).

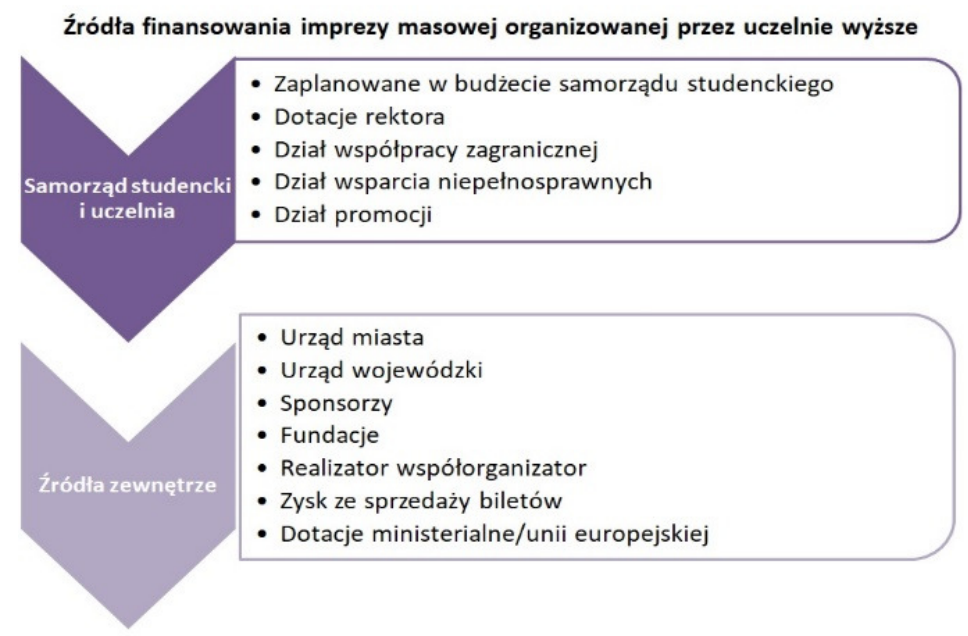

Rysunek 2. Źródta finansowania imprez masowych

Źródto: opracowanie własne.

Podstawowe koszty jakie generuje impreza masowa organizowana przez uczelnię, to: artyści, ZAIKS/STOART/SAWP, scena, nagłośnienie, oświetlenie, wynajem terenu pod imprezę, ogrodzenie festiwalowe, sanitariaty festiwalowe, zabezpieczenie porządkowe, zabezpieczenie medyczne, sprzątanie imprezy/wywóz śmieci, ubezpieczenie imprezy, reklama, gadżety i inne dodatkowe atrakcje.

Ponieważ imprezy masowe adresowane są do różnych grup odbiorców należy wziąć pod uwagę różne formy i narzędzia promocji, w tym social media, strony internetowe lub radio o zasięgu regionalnym.

\section{Imprezy masowe organizowane przez uczelnie}

Wśród imprez masowych organizowanych przez uczelnie wyższe można wymienić: Juwenalia, Dni Otwarte, Festiwale Nauki itp. 
Coroczne święto studentów potocznie zwane Juwenaliami jest organizowane praktycznie w każdym ośrodku naukowym, a nazwa wydarzenia często nawiązuje do specyfiki uczelni lub miasta np. Medykalia, MegaWAT, Cieszynalia czy BBnalia. Przykładem inicjatywy, która zrzesza różne uczelnie i zajmuje się organizacją wspólnych przedsięwzięć jest Porozumienie Samorządów Studenckich Uczelni Śląskich, w skład którego wchodzi 13 samorządów studenckich takich uczelni, jak np. Uniwersytet Śląski, Uniwersytet Ekonomiczny, Politechnika Śląska czy Politechnika Częstochowska. Jednym z wielu zadań porozumienia jest realizacja wspólnych inicjatyw kulturalnych, w tym organizacja corocznego wydarzenia jakim są Juwenalia Śląskie.

Juwenalia Śląskie to impreza, która gromadzi ok. 60000 tys. uczestników. Atrakcje, z których mogą skorzystać uczestnicy to m.in.: korowód Studentów o różnej tematyce np. fantastyka, lata 70 itp., przejęcie kluczy do miasta, imprezy tematyczne takie, jak: karaoke, gry miejskie lub gry planszowe, festiwal muzyczny.

Podobnym charakterem Juwenaliów, choć o mniejszym zasięgu organizacji może się pochwalić Samorząd Studencki Akademii Techniczno-Humanistycznej w Bielsku Białej. Dzięki współpracy z samorządami oraz lokalnymi przedsiębiorcami na terenie całego Podbeskidzia, organizatorzy docierają do szerokiego grona odbiorców. Tydzień Kultury Akademickiej to wydarzenia rozrywkowe, sportowe, kulturalne oraz naukowe tworzące całość Juwenaliów Podbeskidzia. Wydarzenia rozrywkowe to między innymi coroczne, specjalne Juwenaliowe Karaoke w klubie studenckim oraz występy stand'upowe znanych komików, jak również samych studentów. Innym, ważnym punktem Tygodnia Kultury Akademickiej jest konferencja naukowa, spotkanie ze znaną osobą, prelekcje, rywalizacja sportowa, koncerty. Jednym z obowiązkowych punktów Tygodnia Kultury Akademickiej jest „Wielkie Grillowanie" odbywające się na terenie kampusu.

Śląski Festiwal Nauki w Katowicach należy do największych wydarzeń popularnonaukowych w kraju i Europie. W jego organizację zaangażowane są uczelnie z województwa śląskiego, które od 2018 roku na mocy porozumienia utworzyły konsorcjum. Inicjatorem i głównym organizatorem tego wydarzenia jest Uniwersytet Śląski w Katowicach. Gospodarzem festiwalu jest Miasto Katowice, a współgospodarzami - Urząd Marszałkowski Województwa Śląskiego i Górnośląsko-Zagłębiowska Metropolia. Organizacją festiwalu zarządza zespół złożony ze specjalistów z różnych dziedzin. Na festiwalu pojawia się wielu wybitnych przedstawicieli nauki i sztuki reprezentujących zarówno uczelnie krajowe jak i zagraniczne. Jednak największym sukcesem organizatorów jest „wyprowadzenie nauki” poza mury uczelni, do parków, muzeów, siedziby Teatru Śląskiego czy Międzynarodowego Centrum Kongresowego w Katowicach.

Śląski Festiwal Nauki odbywa się w Hali Widowiskowo-Sportowej „Spodek” oraz w Międzynarodowym Centrum Kongresowym. Uczestnicy wydarzenia mają do dyspozycji: punkty gastronomiczne, sale wykładowe, przestronną salę audytoryjną, sale balowe oraz strefy tematyczne.

Akademia Techniczno - Humanistyczna w Bielsku - Białej od ponad dwudziestu lat organizuje Beskidzki Festiwal Nauki i Sztuki. Każda edycja ma swoje hasło przewodnie, które odzwierciedla ideę jaka przyświeca organizatorom: przybliżenie i popularyzacja nauki i sztuki szerokiemu gronu odbiorców. W ramach Festiwalu odbywają się liczne wystawy, pokazy i warsztaty, dla gości otwarte są laboratoria i sale wykładowe. Obowiązkowym punktem każdej edycji festiwalu są liczne 
plenerowe imprezy muzyczne i wydarzenia kulturalne m.in. spektakle, wernisaże, koncerty organizowane na terenie miasta, w okolicznych miejscowościach i całym regionie. Festiwal ma stałe punkty programu, są to: wykład inauguracyjny, Beskidzkie dyktando, Akademia Młodych Talentów, Rynek Scena: gdzie odbywają się spektakle, pokazy, występy taneczne, koncerty muzyczne, wycieczki, wykłady, warsztaty, laboratoria prowadzone przez pracowników uczelni.

W organizację festiwalu zaangażowani są nie tylko pracownicy uczelni ale również funkcjonariusze służb mundurowych: policji, straży pożarnej, nadleśnictwa, wojska, ludzie sztuki - aktorzy, reżyserzy, malarze, graficy, muzycy.

\section{Wyniki badań ankietowych}

Głównym celem przeprowadzonych badań było zweryfikowanie poziomu satysfakcji studentów, którzy brali udział w imprezach masowych organizowanych przez uczelnie wyższe oraz wskazanie czynników, na które organizatorzy imprez powinni zwrócić szczególną uwagę. Kwestionariusz ankietowy został udostępniony na portalach społecznościowych i zawierał 11 pytań oraz metrykę. W badaniu wzięło udział 120 osób, w tym 72 kobiety oraz 48 mężczyzn. Ankietowani zostali podzieleni na trzy grupy wiekowe, tj.: 19-23 lat, 24-26 lat oraz osoby powyżej 26 roku życia. Ponad połowa ankietowanych osób mieściła się w przedziale wiekowym pomiędzy 19 a 23 rokiem życia. Z kolei najmniej liczną grupę stanowiły osoby powyżej 26 roku życia.

W badaniu wzięli udział przedstawiciele takich uczelni wyższych, jak: Akademia Techniczno-Humanistyczna w Bielsku-Białej, Zachodniopomorski Uniwersytet Technologiczny w Szczecinie, Uniwersytet Ekonomiczny w Katowicach, Uniwersytet Mikołaja Kopernika w Toruniu, Politechnika Warszawska, Politechnika Śląska, Politechnika Gdańska, Szkoła Główna Służby Pożarniczej, Wojskowa Akademia Techniczna, Uniwersytet Medyczny we Wrocławiu, Pomorski Uniwersytet Medyczny, Akademia Górniczo-Hutnicza w Krakowie.

Rysunek 3 przedstawia procentowy udział studentów z poszczególnych uczelni.

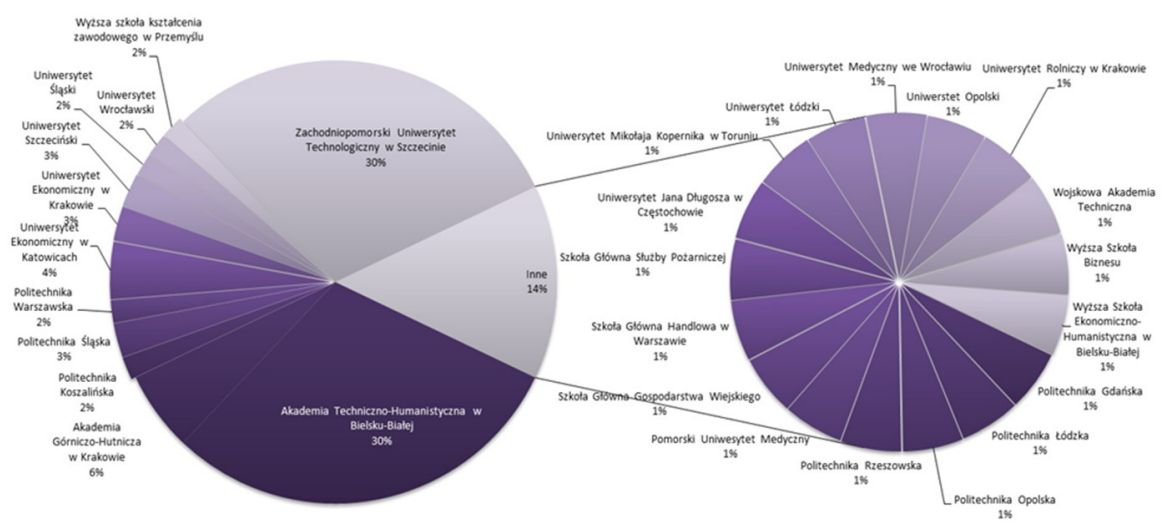

Rysunek 3. Uczelnie wyższe, na których studiują respondenci 
Respondenci zostali zapytani o to, w jakich wydarzeniach masowych brali ostatnio udział. Odpowiedzi badanych osób przedstawiają się następująco: $36 \%$ ankietowanych zadeklarowało, że były to Juwenalia, z kolei udział w Targach pracy wskazało $25 \%$ badanych, natomiast w imprezach tematycznych brało udział $16 \%$ respondentów. Dni otwarte odwiedziło 13\%, a Festiwal Nauki i Sztuki 7\% badanych (rysunek 4).

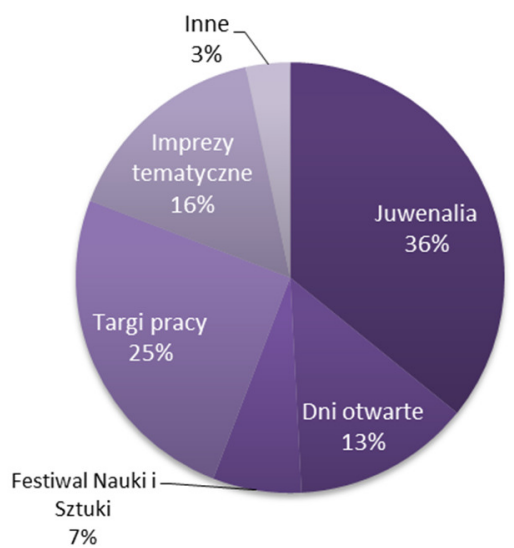

Rysunek 4. Imprezy masowe, w których brali udział ankietowani

Kolejne pytanie zadane respondentom dotyczyło ich zadowolenia z udziału w imprezie masowej organizowanej przez uczelnię wyższą. Ankietowani brali pod uwagę imprezę, w której brali udział w ostatnim czasie. Aż $62 \%$ ankietowanych studentów zadeklarowało swoje zadowolenie $\mathrm{z}$ udziału w imprezie, w której uczestniczyło. $27 \%$ respondentów ocenia poziom swojego zadowolenia jako bardzo dobry a $2 \%$ jako niski (rysunek 5 ).
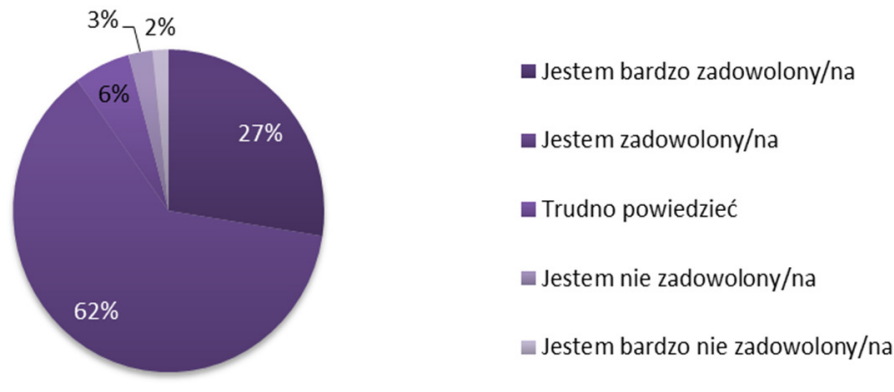

Rysunek 5. Satysfakcja uczestników uczelnianych imprez masowych

Respondentów biorących udział w badaniu ankietowym poproszono o ocenę ważności 14 kryteriów. Ocena kryteriów obejmowała skalę od 1 - 5, gdzie 1 oznaczało kryterium mało ważne a 5 bardzo ważne. Po dokonaniu oceny ważności 14 czynników respondenci oceniali poziom ich spełnienia mając na uwadze ostatnie wydarzenie masowe, w którym brali udział. Zebrane wyniki posłużyły do opracowania macierzy IPA tj. Importance Performance Analysis (rysunek 6). 
Głównym założeniem analizy IPA jest pomiar dwóch zmiennych tj. ważności i oceny. Wybrane do badania kryteria ocenia się pod katem ww. zmiennych. Ocena wykonywana jest najczęściej w skali pięciostopniowej. Wyniki nanosi się na dwuwymiarową macierz, podzieloną na cztery pola decyzje $[1,4]$.

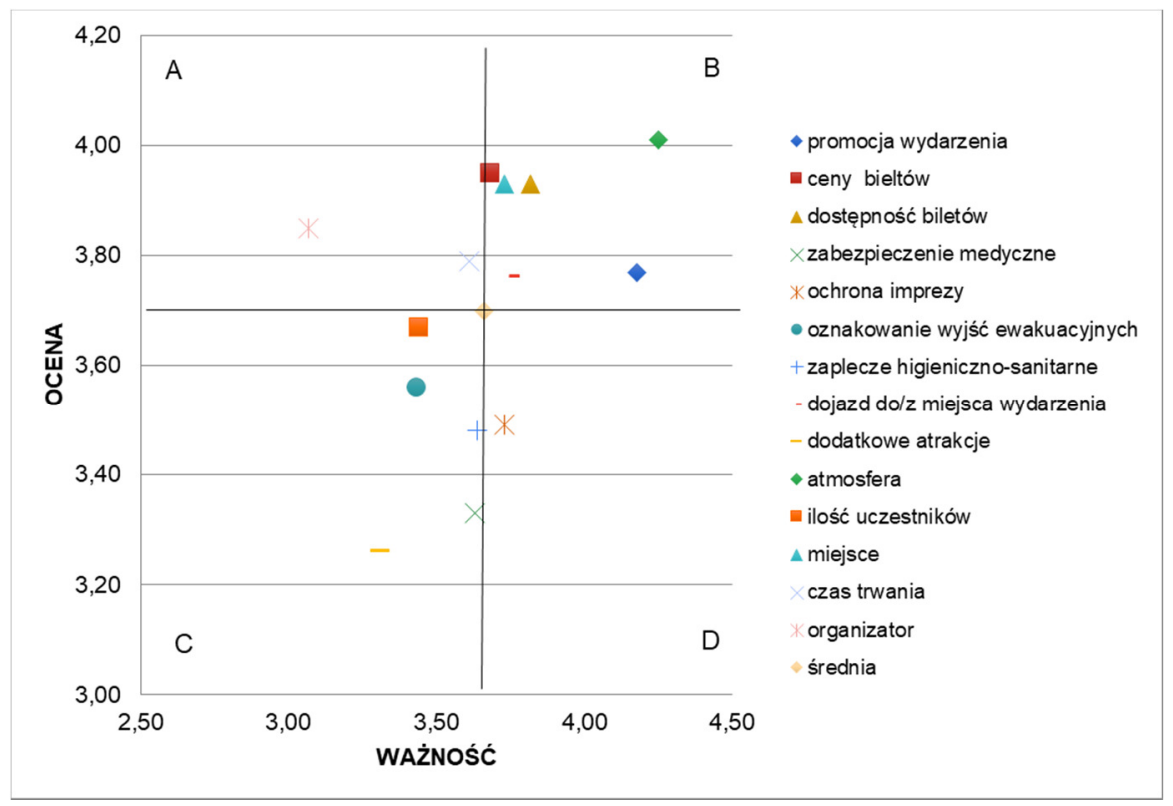

Rysunek 6. Analiza IPA dla wszystkich studentów bioracych udział w badaniu

Ważność czynników, takich, jak: dodatkowe atrakcje, oznakowanie wyjść ewakuacyjnych, ilość uczestników, zabezpieczenie medyczne oraz zaplecze higieniczno-sanitarne jest mała (ćwiartka C). Z kolei czynniki takie, jak: atmosfera wydarzeń, ich promocja, dostępność, miejsce w którym odbywa się wydarzenie, ceny biletów oraz dojazd do/z miejsca wydarzenia są grupą ważnych i wysoko ocenianych czynników (ćwiartka B). Czynnikiem wymagającym poprawy zdaniem respondentów jest ochrona imprezy (ćwiartka D).

Zdaniem respondentów reprezentujących Akademię Techniczno-Humanistyczną w Bielsku-Białej wysoko oceniane i ważne są czynniki takie, jak: ceny biletów, dostępność biletów, czas trwania, miejsce, promocja wydarzenia, dojazd do/z miejsca wydarzenia, atmosfera. W ćwiartce D - „koncentracja wysiłków” nie znalazł się żaden z ocenianych przez respondentów czynników.

Rysunek 7 przedstawia wyniki analizy IPA dla studentów pozostałych uczelni.

Czynniki ważne i wysoko oceniane to: atmosfera, dostępność biletów oraz promocja wydarzenia. Natomiast do czynników wymagających poprawy należą: ochrona imprezy, zaplecze higieniczno-sanitarne oraz zabezpieczenie medyczne. 


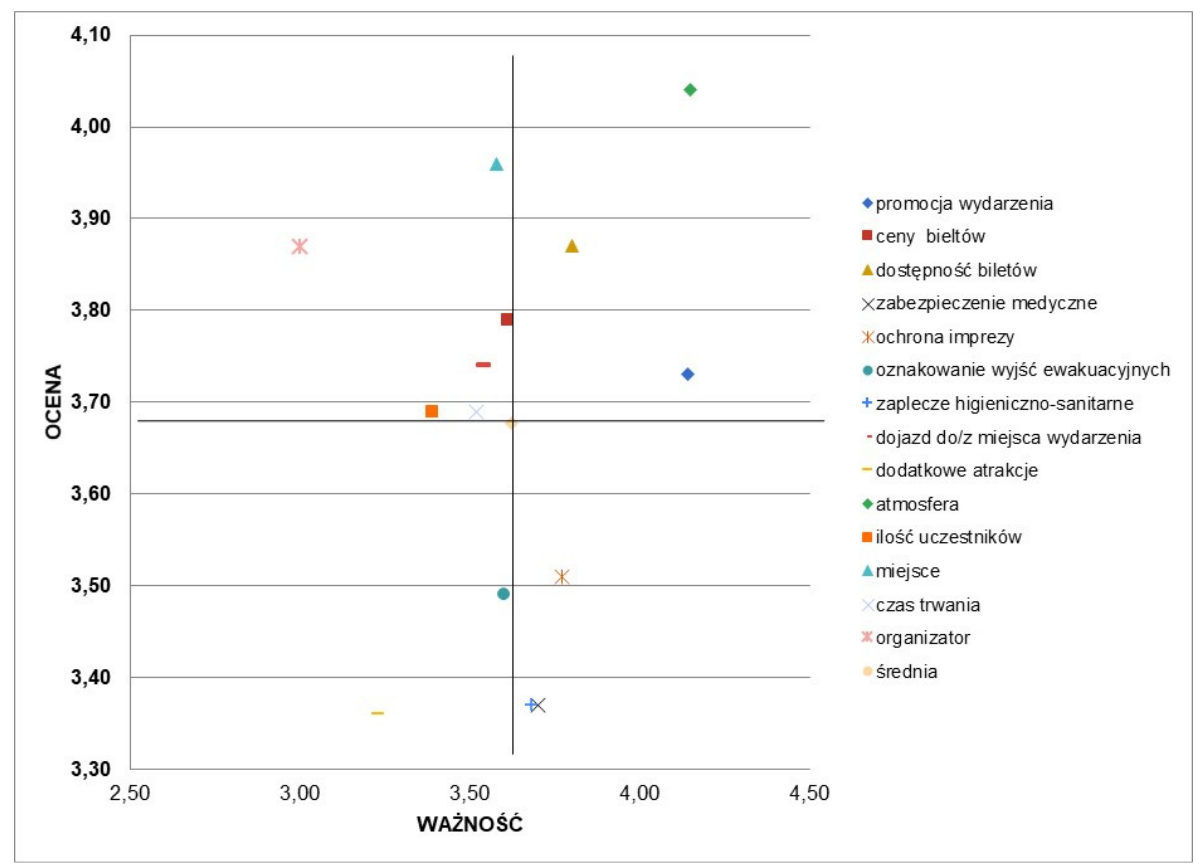

Rysunek 7. Analiza IPA dla studentów pozostatych uczelni

Ważnym aspektem każdej imprezy masowej jest jej repertuar i atrakcje jej towarzyszące. Aby wydarzenie nie utraciło na atrakcyjności i oryginalności według prawie połowy ankietowanych (49\%) organizatorzy powinni co pewien czas konsultować z potencjalnymi uczestnikami przebieg imprezy. 38\% ankietowanych uważa, że organizatorzy powinni takie konsultacje robić przed każdym kolejnym wydarzeniem (rysunek 8).

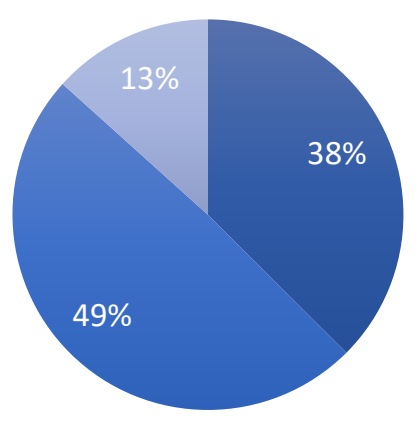

- Powinni to robić zawsze

- Powinni to robić od czasu do czasu

Nie ma potrzeby aby konsultować wydarzenie $\mathrm{z}$ potencjalnymi uczestnikam

Rysunek 8. Konsultowanie repertuaru/atrakcji z uczestnikami imprezy masowej

Jednym $\mathrm{z}$ aspektów ujętych $\mathrm{w}$ badaniu ankietowym był udział ankietowanych w imprezie masowej organizowanej przez uczelnię wyższą biorąc pod uwagę sytuację epidemiologiczną (rysunek 9). 


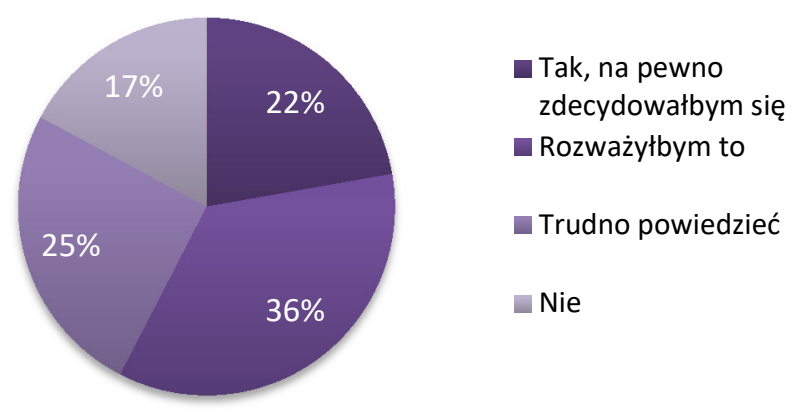

Rysunek 9. Decyzja o wzięciu udziału w imprezie masowej z uwagi na sytuację epidemiologiczna

22\% respondentów zadeklarowało chęć udziału w imprezie masowej pomimo istniejącej sytuacji epidemiologicznej, odpowiedzi pozostałej grupy badanych osób przedstawiają się następująco: opcję uczestnictwa w imprezie masowej rozważyłoby - 36\% badanych, zdania na ten temat nie ma 25\% respondentów, $17 \%$ badanych zdecydowanie nie wzięłoby udziału w takim wydarzeniu.

\section{Podsumowanie}

Imprezy masowe łączą społeczność akademicką, mieszkańców miasta, organizacje i instytucje, są okazją do integracji i aktywizacji lokalnej społeczności.

Organizacja imprezy masowej jest zadaniem trudnym i wymagającym zwłaszcza jeśli chodzi o kwestie dotyczące bezpieczeństwa uczestników. Wyniki badań ankietowych przeprowadzone na próbie 120 respondentów pokazały, że organizatorzy imprez masowych powinni zadbać o takie aspekty, jak: ochrona imprezy, zaplecze higieniczno-sanitarne oraz zabezpieczenie medyczne. Ponadto zdaniem respondentów organizatorzy uczelnianych imprez masowych powinni co jakiś czas konsultować ich przebieg z uczestnikami.

Ważną kwestią dla wszystkich organizatorów imprez masowych jest zadowolenie uczestników. Analiza wyników badań ankietowych wykazała, że satysfakcja respondentów biorących udział w imprezach masowych organizowanych przez uczelnie wyższe jest duża.

\section{LITERATURA}

1. BIESOK G. i WYRÓD-WRÓBEL J. Podejście do analizy IPA w badaniach satysfakcji klienta. Problemy Jakości, 2015, 6, s. 26-31.

2. CHAŁPOWSKI J. Impreza sportowa jako produkt w ujęciu marketingowym. [w:] (red.) H. Mruk, K. Kropielnicki, P. Matecki, Marketing dla sportu, Poznań 2006. 
3. CIEŚLIKOWSKI K., KANTYKA J. Wykorzystanie wielkich wydarzeń w promocji miasta - na przykładzie Katowic. Zeszyty Naukowe Uczelni Vistula, 2015, 40, s. 29-41.

4. MARTILLA J.A. and JAMES J.C. Importance-Performance Analysis. Journal of Marketing, 1977, 41, p. 77-79.

5. PARSZOWSKI S., KRUCZYŃSKI A. Imprezy masowe, organizacja, bezpieczeństwo, dobre praktyki. Warszawa, Difin 2015.

6. SIENKIEWICZ P., GÓRNY P., ŚWIEBODA H. Aspekty systemowe zarządzania bezpieczeństwem. [w:] Służby mundurowe w systemie bezpieczeństwa EURO 2012. (red.) M. Marszałek, A. Glen, B. Wiśniewski, Sieradz 2009.

7. SŁODCZYK J. (red.) Rozwój miast i zarzadzanie gospodarką miejską, Wydawnictwo Uniwersytetu Opolskiego, Opole 2004.

8. SUSKI P. Zgromadzenia i imprezy masowe. Warszawa, LexisNexis 2010.

9. SZROMNIK A. Marketingowa koncepcja przedsięwzięcia sportowego. Sport\&Business Foundation, Poznań 2006.

10. Ustawa z dnia 20 marca 2009 r. o bezpieczeństwie imprez masowych. Dz. U. $2009 \mathrm{Nr} 62$ poz. 50. 
